\title{
The effect of dietary propolis and pollen extracts on growth performance and haematological responses of rainbow trout (Onchorhynchus mykiss)
}

\author{
N Choobkar', S Kakoolaki*2, F Mohammadi ${ }^{3}$, M Rezaeimanesh ${ }^{4}$ \\ ${ }^{1}$ Department of Fisheries, Kermanshah branch, Islamic Azad University, Kermanshah, Iran \\ ${ }^{2}$ Iranian Fisheries Science Research Institute (IFSRI), Agricultural Research Education and Extension \\ Organization (AREEO), Tehran, Iran \\ ${ }^{3}$ Department of Veterinary, Kermanshah branch, Islamic Azad University, Kermanshah, Iran \\ ${ }^{4}$ Department of Environment Science, Faculty of Environment, University of Environment Karaj, Iran
}

\begin{abstract}
The aim of this study was to determine the effect of propolis and pollen extract on biochemical and haematological parameters of Onchorhynchus mykiss. One hundred and eighty healthy fish, O. mykiss (mean weight $20.57 \pm 4.48$ g) were used for growth performance and haematological assays. They were randomly selected, and distributed among fifteen $600-\mathrm{L}$ fiberglass tanks as three treatments (1\% Pollen, $1 \%$ Proplils, $0.5 \%$ Pollen $+0.5 \%$ Proplils as groups 1-3, respectively), negative control as group 4 in triplicates at density of 30 fish each.
\end{abstract}

Correspondence S Kakoolaki, Iranian Fisheries Science Research Institute (IFSRI), Agricultural Research Education and Extension Organization (AREEO), Tehran, Iran (e-mail: bsh443@gmail.com)
After 8 weeks of the experiment, which the fish fed supplemented diets, final weight of all treatments showed no significant difference $(p>$ $0.05)$ as well as WG and DGI. Definitely, all the treatments of the mentioned criteria showed a significant increase $(\mathrm{p}<0.05)$ compared to control group. On the other hand, FCR showed a significance difference $(\mathrm{p}=0.00)$ among the treatments and control so that its value for the group 3 was the minimum one $(1.84 \pm 0.05)$ and followed by group $2(2.36 \pm 0.03)$. Some criteria containing $\mathrm{Hb}, \mathrm{RBC}$, Hct and WBC showed a remarkable increase $(\mathrm{p}<0.05)$ in group 3 compared to other groups while $\mathrm{MCV}$ and $\mathrm{MCH}$ was significantly lower in group $3(\mathrm{p}<0.05)$.

Keywords: herbal medicine, Pollen, Propolis, Onchorhynchus mykiss, haematology 


\section{Introduction}

Growth in the global supply of fish for human consumption has outperformed population growth particularly in the past 50 years, increasing at an average annual rate of 3.2 percent in the period 1961- 2013, double that of population growth, resulting in increasing average per capita availability World per capita apparent fish consumption increased from an average of $9.9 \mathrm{~kg}$ in the $1960 \mathrm{~s}$ to $14.4 \mathrm{~kg}$ in the $1990 \mathrm{~s}$ and $19.7 \mathrm{~kg}$ in 2013, with preliminary estimates for 2014 and 2015 pointing towards further growth beyond $20 \mathrm{~kg}$ (FAO 2016). Initially, much of this demand was met by wildcaught fish, but as world fisheries continue to be over-exploited and depleted, aquaculture systems have undergone unprecedented growth, evolving as a significant contributor to meet demands for cultured aquatics (Sapkota, Sapkota, Kucharski, Burke, McKenzie, Walker \& Lawrence 2008). Among the fish species, Onchorhynchus mykiss has been expanded and The share of salmon and trout in world trade has increased strongly in recent decades (16\% of the world value share of aquatics), becoming the largest single commodity by value in 2013(FAO 2014). Anyhow the necessity to rear sufficient quantities of resistant fry is becoming crucial to meet the increasing global demands for stocking rainbow trout farms (Soltani, Pirali, Rasoli, Kakoolaki \& Shams 2014).

Small amounts of agrichemicals can reach aquaculture ponds, which results in numerous problems caused by oxidative stress in non- target organisms. Substances that can prevent or reverse agrichemical-induced oxidative damage may be used to combat these effects (Ferreira, Rocha, Kreutz, Loro, Marqueze, Koakoski, da Rosa, Gusso, Oliveira \& de Abreu 2013).

Propolis (bee glue) is a natural dark-coloured, resinous sticky substance produced by honey bees by mixing their own waxes with resins collected from plants, and is used as a sealant and sterilant in their nests (Sforcin, Fernandes, Lopes, Bankova \& Funari 2000, Moreira, Dias, Pereira \& Estevinho 2008, Kakoolaki, Talas, Cakir, Ciftci \& Ozdemir 2013). Propolis has been used since ancient times as a medicine owing to those biological properties as an antifungal, antiprotozoal, antimicrobial, and antiviral agent. Propolis has antioxidant properties (Selamoglu Talas \& Gulhan 2009). The main chemical classes found in propolis are flavonoids and phenolics. Bioflavonoids are antioxidant molecules that play important roles in scavenging free radicals, which are produced in neurodegenerative diseases and aging (Selamoglu Talas, Pinar Dundar, Fuat Gulhan, Orun \& Kakoolaki 2012). The negative effects after exposure the fish to cypermethrin, could be inverted by adding supplementation propolis. Propolis may improve some biochemical markers associated with oxidative stress in fish brain (Kakoolaki et al. 2013). propolis can improve biochemical and hematologic functions of common carp blood, after being exposed to arsenic (Selamoglu Talas et al. 2012). 
The aim of this study was to determine the effect of propolis and pollen extract on biochemical and haematological parameters of O. mykiss.

\section{Materials and Methods}

\section{Fish and experimental design}

One hundred and eighty healthy fish, O. mykiss (mean weight $20.57 \pm 4.48 \mathrm{~g}$ ) were used for growth performance and haematological assays. They were randomly selected, and distributed among fifteen 600-L fiberglass tanks as three treatments (1\% Pollen, $1 \%$ Proplils, $0.5 \%$ Pollen $+0.5 \%$ Proplils as groups 1-3, respectively), negative control as group 4 in triplicates at density of 30 fish each. The tanks were prefilled with 200-L filtered well-aerated freshwater (water flow: $6 \mathrm{~L} / \mathrm{h}$, temperature: $15.50 \pm 1.0$ and $\mathrm{pH}: 6.8 \pm 0.1$, dissolved oxygen 7.1, $\mathrm{pH} 7.8$ ). Fish were fed ad libitum 4 times a day with Iranian Beiza commercial fishmeal with gross energy level of $4.30 \mathrm{cal} / \mathrm{g}$ for 8 -week containing either pollen $(1 \%)$, or propolis $(1 \%)$, or combination of pollen $(0.5 \%)$ and propolis $(0.5 \%)$ and control group for 8 weeks. They were kept at the ambient, uncontrolled temperature of $15 \pm 1.0 \quad{ }^{\circ} \mathrm{C}$ under natural photoperiod.

\section{Crude propolis, pollen and ethanolic-extract} Propolis and pollen ethanolic-extract was prepared by adding $30 \mathrm{ml}$ of absolute ethanol to $3 \mathrm{~g}$ of them in bottles, which were sealed and kept from light and moderately shaken for 1 day at room temperature. The extract was then filtered twice, dried and stored in sealed bottles at $4^{\circ} \mathrm{C}$ until use (Abd-El-Rhman 2009). They were used in combination with food as $1 \%$ during the experiment.

\section{Blood sampling and serum preparation}

Fish were anaesthetized by immersing the fish in water containing $30 \mathrm{ppm}$ of clove powder, 9 fish were randomly sampled from each group and replicates. The blood samples directly withdrawn from heart of each fish 8 weeks after start of experiment using 1-ml heparinated syringe to evaluate hamatocrit and differential white blood count (Abd-El-Rhman 2009) and non-heparinated syringes (used for serum examinations) connected to 24-gauge needle (Dinakaran Michael, Srinivas, Sailendri \& Muthukkaruppan 1994). For serum preparation, $500 \mu \mathrm{l}$ of drawn blood kept in serological tubes were left the clot to be performed at a refrigerator temperature overnight. The clotted blood was centrifuged at $700 \mathrm{~g}$ for $30 \mathrm{~min}$ at 4 ${ }^{\circ} \mathrm{C}$ and kept at $-20{ }^{\circ} \mathrm{C}$ until use.

\section{Haematological Analysis}

Blood smears were stained with Natt-Herrick's solution (1:200 for both blood cells) to count RBC $\left(10^{6} \mathrm{~mm}^{-3}\right)$ and white blood cells (WBC) $\left(10^{4} \mathrm{~mm}^{-3}\right)$ using a hemocytometer (Grant 2015). Giemsa stained blood smears were separately prepared for differential WBC counts (\%). Therefore, Two hundred leukocytes, including such types as lymphocytes, monocytes and granulocytes from each prepared smear, were counted under a light microscope (Dacie \& Lewis 2001). 
In order to measure the Hematocrit $(\mathrm{Ht})$, the blood-filled heparinized tubes were centrifuged at $10000 \mathrm{~g}$ for $5 \mathrm{~min}$ in a hematocrit centrifuge. The results were then read using a scale hematocrit reader. Hemoglobin $(\mathrm{Hb})$ were calculated by photometric assay of cyanomethemoglobin method and the haematological parameters of mean cell hemoglobin concentration (MCHC), mean cell hemoglobin $(\mathrm{MCH})$ and mean cell volume (MCV) were measured following Dacie and Lewis (2001). The equations for haematological factors are as follows:

$\mathrm{MCV}(\mathrm{fL})=[(\mathrm{Hct}, \%) \times 10] /\left(\mathrm{RBC}, 10^{6} \mathrm{per}\right.$ $\left.\mathrm{mm}^{3}\right)$

$\mathrm{MCH}\left(\mathrm{pg}\right.$ cell $\left.^{-1}\right)=[(\mathrm{Hb}, \mathrm{g} / \mathrm{dL}) \times 10] /\left(\mathrm{RBC}, 10^{6}\right.$ per $\mathrm{mm}^{3}$ )

$\operatorname{MCHC}(\%)=[(\mathrm{Hb}, \mathrm{g} / \mathrm{dL}) \times 100] /(\mathrm{Hct}, \%)$

Total Plasma Protein (TPP), Albumin and Globulin

A commercial protein-kit (Pars Azmoon, Tehra, Iran) was used based on the procedure of Biuret reaction to measure TPP content. Nine ml Nacl $(0.85 \%)$ was added to $0.1 \mathrm{ml}$ plasma in an ependorf micro tubes and $1.9 \mathrm{ml} \mathrm{Nacl}(0.85 \%)$ was added to $0.1 \mathrm{ml}$ standard solution in another micro tube accompanied with $2 \mathrm{ml}$ reagent blank in the third tube. Five ml diluted Biuret solution was added to each tube in triplicates, which were then gently mixed. After $20 \mathrm{~min}$ of incubation at room temperature, absorbance was measured with a multi-scan spectrophotometer
(WPAS2000-UV/VIS, Cambridge, UK) at 550 $\mathrm{nm}$ and TPP values were expressed in $\mathrm{g} \mathrm{dL}^{-}$ ${ }^{1}$ (Ardó, Yin, Xu, Váradi, Szigeti, Jeney \& Jeney 2008). Globulin was calculated by deducing albumin from TPP and Albumin were assayed by colorimetric method using bromocresol green binding procedure (Oskoii, Kohyani, Parseh, Salati \& Sadeghi 2012). Additionally, Albumin/globulin $(\mathrm{A} / \mathrm{G})$ ratio was determined for the experiment and the control groups (Harikrishnan, Kim, Kim, Balasundaram \& Heo 2011).

\section{Growth Performance}

The initial (4-week) and final (8-week) weights of 15 fish in each group and replications were used to calculate the growth performance according to Harikrishnan, Balasundaram and Heo (2012). This was performed as follows:

$\mathrm{WG}(\%)=\left(\mathrm{W}_{\mathrm{f}}-\mathrm{W}_{\mathrm{i}} / \mathrm{W}_{\mathrm{i}}\right) \times 100$

Where, $\mathrm{WG}, \mathrm{W}_{\mathrm{f}}$ and $\mathrm{W}_{\mathrm{i}}$ were weight gain, mean final body weight and mean initial body weight, respectively. Additionally, $\mathrm{W}_{\mathrm{f}}$ or $\mathrm{W}_{\mathrm{i}}$ of each replication was calculated by dividing total fish weight in each tank by the number of fish (AbdEl-Rhman 2009).

$\operatorname{DGI}(\%)=\frac{[(\mathrm{WG} \times 100) /(\mathrm{Wi}+\mathrm{Wf}) / 2)]}{\mathrm{t}}$

Where, DGI, Wi and Wf were daily growth index, initial body weight and final body weight, respectively. 
FCR $($ feed conversion ratio) $=$ feed supplied $(\mathrm{g}$, dry weight)/body weight gain (g).

\section{Statistical analysis}

Multiple group comparisons were performed by means of One-way ANOVA followed by Bonferroni's test for post hoc comparison. Statistics analyses and plotting the figures were performed using SPSS software version 16.0 (SPSS Inc. Chicago, Illinois, USA) and Excel 2010 software, respectively. The comparisons considered significant at $p<0.05$.
In order to determine the effects of

supplemented diets on O. mykiss, growth performance of the fish fed basal diet supplemented with Propolis and pollen ethanolic-extract was summarized in Table 1. There was no significant difference $(p>0.05)$ was observed among the initial weights of the treatments. After 8 weeks of the experiment, which the fish fed supplemented diets, final weight of all treatments showed no significant difference $(p>0.05)$ as well as WG and DGI (Table 1).

\section{Results}

Table 1 Growth performance of Onchorhynchus mykiss fed basal diet supplemented with Propolis and pollen ethanolic-extract the end of experiment

\begin{tabular}{lll}
\hline Growth parameters & Doses $(\mathrm{mg} / \mathrm{kg})$ & Week 8 \\
\hline $\mathrm{W}_{\mathrm{i}}(\mathrm{g})$ & 1\% Pollen & $6.3 \pm 0.08$ \\
& 1\% Proplils & $6.3 \pm 0.09$ \\
& 0.5\% of Pollen \& Propolis & $6.2 \pm 0.06$ \\
& Control & $6.3 \pm 0.07$ \\
$\mathrm{~W}_{\mathrm{f}}(\mathrm{g})$ & & \\
& 1\% Pollen & $50.1 \pm 0.34^{\mathrm{a}}$ \\
& 1\% Proplils & $50.3 \pm 0.35^{\mathrm{a}}$ \\
& 0.5\% of Pollen \& Propolis & $50.2 \pm 0.36^{\mathrm{a}}$ \\
& Control & $41.4 \pm 0.63^{\mathrm{b}}$ \\
$\mathrm{WG}(\%)$ & \\
& 1\% Pollen & $690.36 \pm 10.59^{\mathrm{a}}$ \\
& 1\% Proplils & $675.76 \pm 11.01^{\mathrm{a}}$ \\
& $0.5 \%$ of Pollen \& Propolis & $714.74 \pm 11.31^{\mathrm{a}}$ \\
& Control & $561.25 \pm 9.85^{\mathrm{b}}$ \\
& & \\
$\mathrm{DGI}(\mathrm{g})$ & 1\% Pollen & $0.24 \pm 0.0^{\mathrm{a}}$ \\
& 1\% Proplils & $0.24 \pm 0.0^{\mathrm{a}}$ \\
& $0.5 \%$ of Pollen \& Propolis & $0.25 \pm 0.0^{\mathrm{a}}$ \\
& Control & $0.24 \pm 0.0^{\mathrm{a}}$ \\
$\mathrm{FCR}$ & 1\% Pollen & $2.67 \pm 0.03^{\mathrm{a}}$ \\
& 1\% Proplils & $2.36 \pm 0.03^{\mathrm{b}}$ \\
& $0.5 \%$ of Pollen \& Propolis & $1.84 \pm 0.05^{\mathrm{c}}$ \\
& Control & $2.66 \pm 0.04^{\mathrm{a}}$ \\
\hline
\end{tabular}

Data expressed as mean $\pm \mathrm{SE}, n=15$. $\mathrm{W}_{\mathrm{i}}$ : weight initial, $\mathrm{W}_{\mathrm{f}}$ : weight final $\mathrm{WG}$ : weight gain,

DGI: daily growth index, FCR: feed conversion ratio, In each column and growth 
parameter, different letters indicate significant difference among concentrations $(\mathrm{P}<0.05)$

by Bonferroni's test.

Definitely, all the treatments of the mentioned criteria showed a significant increase $(\mathrm{p}<0.05)$ compared to control group. On the other hand, FCR showed a significance difference $(p=0.00)$ among the treatments and control so that its value for the group 3 was the minimum one $(1.84 \pm 0.05)$ and followed by group 2 (2.36 \pm 0.03$)$, which that of the former showed a lower value. There was no significance difference $(p>0.05)$ between the group 1 and control.
The plasma parameters were shown in Fig. 1. There was no significant difference ( $p>$ 0.05 ) between groups 1 and 2 of TPP while the maximum value $(3.2 \pm 0.2)$ was calculated for group 3 (Fig. 1). No significant difference (p> 0.05) was observed among the groups of globulin. A significant increase $(p<0.05)$ was shown in group 3 of albumin while no significant difference ( $p>0.05$ ) was observed among other groups (Fig. 1).

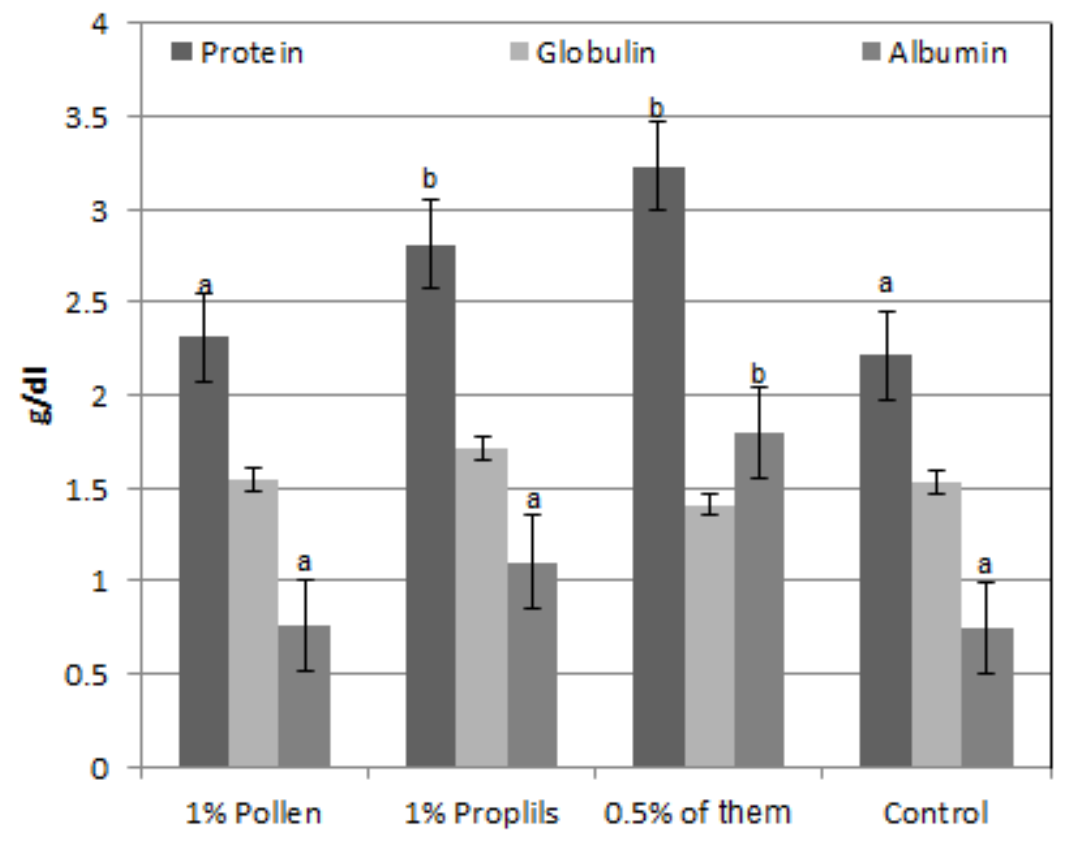

Figure 1 Plasma parameters, protein $(\mathrm{g} / \mathrm{dL})$, globulin $(\mathrm{g} / \mathrm{dL})$ and albumin $(\mathrm{g} / \mathrm{dL})$ of groups fed with Propolis and pollen ethanolic-extract supplemented diets at different concentrations. Data expressed as mean $\pm \mathrm{SE}(\mathrm{n}=9)$. In same color, different letters indicate significant difference $(\mathrm{P}<0.05)$ by Bonferroni's test.

Table 2 shows the haematological parameters. Some criteria containing $\mathrm{Hb}, \mathrm{RBC}$, Hct and WBC showed a remarkable increase $(\mathrm{p}<0.05)$ in group 3 compared to other groups while MCV and $\mathrm{MCH}$ was significantly lower in group 3 (p< $0.05)$. 
Table 2 Haematological indices of of Onchorhynchus mykiss fed supplemented diets after 8 weeks of feeding

\begin{tabular}{lllll}
\hline $\begin{array}{l}\text { Haematological } \\
\text { indices }\end{array}$ & $1 \%$ Pollen & $1 \%$ Proplils & $\begin{array}{l}0.5 \% \text { of Pollen } \\
\& \text { Propolis }\end{array}$ & Control \\
\hline $\mathrm{Hb}\left(\mathrm{g} \mathrm{dl}^{-1}\right)$ & $8.1 \pm 0.2^{\mathrm{a}}$ & $8.6 \pm 0.1^{\mathrm{a}}$ & $9.2 \pm 0.1^{\mathrm{b}}$ & $8.2 \pm 0.2^{\mathrm{a}}$ \\
$\mathrm{RBC}\left(\times 10^{6} \mathrm{~mm}^{-3}\right)$ & $1.5 \pm 0.0^{\mathrm{a}}$ & $1.8 \pm 0.0^{\mathrm{ab}}$ & $2.5 \pm 0.1^{\mathrm{c}}$ & $2.0 \pm 0.0^{\mathrm{b}}$ \\
$\mathrm{Hct}(\%)$ & $23.2 \pm 0.2^{\mathrm{a}}$ & $24.1 \pm 1.3^{\mathrm{a}}$ & $28.7 \pm 0.6^{\mathrm{b}}$ & $24.5 \pm 0.5^{\mathrm{a}}$ \\
$\mathrm{MCV}(\mathrm{fL})$ & $164.9 \pm 2.5^{\mathrm{a}}$ & $149.7 \pm 3.3^{\mathrm{b}}$ & $116.3 \pm 4.19^{\mathrm{c}}$ & $123.3 \pm 3.5^{\mathrm{d}}$ \\
$\mathrm{MCH}\left(\mathrm{pg} \mathrm{cell}{ }^{-1}\right)$ & $53.0 \pm 1.0^{\mathrm{a}}$ & $48.4 \pm 1.2^{\mathrm{b}}$ & $37.5 \pm 1.4^{\mathrm{c}}$ & $41.1 \pm 0.7^{\mathrm{c}}$ \\
$\mathrm{MCHC}(\%)$ & $32.1 \pm 0.2$ & $32.3 \pm 0.2$ & $32.2 \pm 0.2$ & $33.4 \pm 0.5$ \\
$\mathrm{WBC}\left(\times 10^{4} \mathrm{~mm}-3\right)$ & $50.2 \pm 0.7^{\mathrm{a}}$ & $55.4 .0 \pm 0.7^{\mathrm{b}}$ & $67.8 \pm 0.7^{\mathrm{c}}$ & $56.3 \pm 1.0^{\mathrm{b}}$ \\
\hline
\end{tabular}

Value expressed as mean \pm SE $(n=9)$. For each index, different letters indicate significant difference among concentrations $(\mathrm{P}<0.05)$ by Bonferroni's test.

\section{Discussion}

This study highlights pollen and propolis extracts as a food additive for $O$. mykiss, which demonstrated improved growth performance. In this study, we demonstrated that propolis and Pollen extracts had effect on growth performance as final weight of $O$. mykiss of whole treatments either fed propolis or pollen compared to control group. the higher intestinal absorption because of longer villi of digestive tract of the fish (Wang, Li, Wang, Xin \& Wang 2007), efficacy of conversion the feed to protein (Attia, Al-Hanoun, Tag El-Din, Bovera \& Shewika 2011). This higher intestinal absorption may be due to longer villi of digestive tract of the fish for trapping better propolis and pollen (Wang et al. 2007) or efficacy of conversion the feed to protein (Attia et al. 2011). From the data in table 1, it is apparent that the feed conversion ratio for the fish fed diet supplemented with a mixture of propolis and pollen ( $0.5 \%$ of Pollen \& Propolis) was more effective on decreasing the feed consumption with increasing the weight compared to the fish fed propolis or pollen alone. This growth performance, which occurred with the mixture of pollen and propolis could be due to pollen and propolis contents such as vitamins, minerals, enzymes or coenzymes, which promote food digestion $(\mathrm{Xu}$, Sun, Dong \& Zhang 2009). On the other hand, it may be that the dose of $1 \%$ of the extract had inverse effect on growth of $O$. mykiss. Selamoglu Talas and Gulhan (2009) confirm that the greater dose of propolis has inverse effect on growth of $O$. mykiss. Against, A research (El-Asely, Abbass \& Austin 2014) conducted on Oreochromis niloticus showed significant increase in final weight with $1 \%$ pollen extract. Ferreira et al. (2013) showed that the antioxidant properties of propolis and pollen are viable alternatives with 
low environmental impact on catfish, Rhamdia quelen. They showed increases in the enzymatic activities, which have more protective effects of bee products against oxidative stress.

A research confirmed that the decline of the albumin portions which were most significantly associated with the hypoproteinaemia. The low level of albumin may be the result of losses from the skin lesions, an increased catabolism in acute inflammation or reduced synthesis due to hepatopathy, or may be

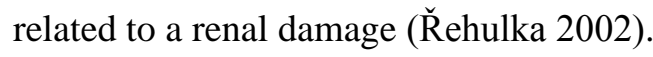

A drop in the values of $\mathrm{RBC}$ and $\mathrm{Hb}$, concerning the symptoms of anaemia (̌rehulka 2002) and nutritional deficiency or disease of fish is always associated with decline of Hct (ElAsely et al. 2014). Therefore, the haematological examination can shows the fish health status. In this study the value of RBC of the fish fed with $1 \%$ Pollen and $1 \%$ Propolis was significantly lower than control group while MCV and $\mathrm{MCH}$ were higher, which shows an anaemia occurred in the fish. These symptoms could be due to the effect of higher concentrations of propolis and pollen extract on haematopoiesis centers in $O$. mykiss. Decrease in level of RBC, $\mathrm{Hb}$ and Hct is associated with higher doses of propolis in $O$. mykiss may be a sign of anemia with inhibition of erythropoesis in the hemopoetic organs. In addition, increases in $\mathrm{MCV}, \mathrm{MCH}$ and $\mathrm{MHCH}$ values indicated that the anemia was a macrocytic type (Selamoglu Talas \& Gulhan 2009). As this results showed, the albumin and protein levels of plasma were increased in treatment-dependent number and was significantly higher than that of the control group. This increase shows a positive effect of pollen and propolis at the study concentration on fish health status.

$$
\text { It is concluded that the diet }
$$
supplemented with mixture of $0.5 \%$ pollen and $0.5 \%$ propolis is more effective than $1 \%$ pollen or $1 \%$ propolis alone on $O$. mykiss growth performance as well as plasma and haematological parameters, which show the fish heath status.

\section{References}

Abd-El-Rhman, A.M. (2009) Antagonism of Aeromonas hydrophila by propolis and its effect on the performance of Nile tilapia, Oreochromis niloticus. Fish \& shellfish immunology 27(3), 454-459.

Ardó, L., Yin, G., Xu, P., Váradi, L., Szigeti, G., Jeney, Z. \& Jeney, G. (2008) Chinese herbs (Astragalus membranaceus and Lonicera japonica) and boron enhance the non-specific immune response of Nile tilapia (Oreochromis niloticus) and resistance against Aeromonas hydrophila. Aquaculture 275(1), 26-33.

Attia, Y., Al-Hanoun, A., Tag El-Din, A., Bovera, F. \& Shewika, Y. (2011) Effect of bee pollen levels on productive, reproductive and blood traits of NZW rabbits. Journal of animal physiology and animal nutrition 95(3), 294-303.

Dacie, J.V. \& Lewis, S.M. (2001) Miscellaneous tests. Churchill Livingstone, Dacie and Lewis practical haematology.

Dinakaran Michael, R., Srinivas, S., Sailendri, K. \& Muthukkaruppan, V. (1994) A rapid method for repetitive bleeding in fish. Indian Journal of Experimental Biology 32, 838-838.

El-Asely, A.M., Abbass, A.A. \& Austin, B. (2014) Honey bee pollen improves growth, 
immunity and protection of Nile tilapia (Oreochromis niloticus) against infection with Aeromonas hydrophila. Fish \& shellfish immunology 40(2), 500-506.

FAO (2014) The state of the world fisheries and aquaculture. Rome, FAO.

FAO (2016) The state of world Fisheries and Aquaculture. Rome.

Ferreira, D., Rocha, H.C., Kreutz, L.C., Loro, V.L., Marqueze, A., Koakoski, G., da Rosa, J.G.S., Gusso, D., Oliveira, T.A. \& de Abreu, M.S. (2013) Bee products prevent agrichemicalinduced oxidative damage in fish. PloS one 8(10), e74499.

Grant, K.R. (2015) Fish hematology and associated disorders. Veterinary Clinics of North America: Exotic Animal Practice 18(1), 83-103.

Harikrishnan, R., Balasundaram, C. \& Heo, M.S. (2012) Effect of Inonotus obliquus enriched diet on hematology, immune response, and disease protection in kelp grouper, Epinephelus bruneus against Vibrio harveyi. Aquaculture 344, 48-53.

Harikrishnan, R., Kim, J.-S., Kim, M.-C., Balasundaram, C. \& Heo, M.-S. (2011) Styrax japonica supplementation diet enhances the innate immune response in Epinephelus bruneus against bacterial and protozoan infections. Experimental parasitology 129(3), 260-265.

Kakoolaki, S., Talas, Z.S., Cakir, O., Ciftci, O. \& Ozdemir, I. (2013) Role of Propolis on Oxidative Stress in Fish Brain. Basic and Clinical Neuroscience 4(2), 153-158.

Moreira, L., Dias, L.G., Pereira, J.A. \& Estevinho, L. (2008) Antioxidant properties, total phenols and pollen analysis of propolis samples from Portugal. Food and Chemical toxicology 46(11), 3482-3485.

Oskoii, S.B., Kohyani, A.T., Parseh, A., Salati, A.P. \& Sadeghi, E. (2012) Effects of dietary administration of Echinacea purpurea on growth indices and biochemical and hematological indices in rainbow trout (Oncorhynchus mykiss) fingerlings. Fish physiology and biochemistry 38(4), 1029-1034.

Řehulka, J. (2002) Aeromonas causes severe skin lesions in rainbow trout (Oncorhynchus mykiss): clinical pathology, haematology, and biochemistry. Acta Veterinaria Brno 71(3), 351360 .

Sapkota, A., Sapkota, A.R., Kucharski, M., Burke, J., McKenzie, S., Walker, P. \& Lawrence, R. (2008) Aquaculture practices and potential human health risks: current knowledge and future priorities. Environment international 34(8), 1215-1226.

Selamoglu Talas, Z. \& Gulhan, M.F. (2009) Effects of various propolis concentrations on biochemical and hematological parameters of rainbow trout (Oncorhynchus mykiss). Ecotoxicology and Environmental Safety 72(7), 1994-1998.

Selamoglu Talas, Z., Pinar Dundar, S., Fuat Gulhan, M., Orun, I. \& Kakoolaki, S. (2012) Effects of propolis on some blood parameters and enzymes in carp exposed to arsenic. Iranian Journal of Fisheries Sciences 11(2), 405-414.

Sforcin, J., Fernandes, A., Lopes, C., Bankova, V. \& Funari, S. (2000) Seasonal effect on Brazilian propolis antibacterial activity. Journal of Ethnopharmacology 73(1), 243-249.

Soltani, M., Pirali, E., Rasoli, A., Kakoolaki, S. \& Shams, G. (2014) Antibiotic residuals in some farmed rainbow trout(Oncorhynchus mykiss) of market size in Iran. Iranian Journal of Aquatic Animal Health 1(1), 71-77.

Wang, J., Li, S., Wang, Q., Xin, B. \& Wang, H. (2007) Trophic effect of bee pollen on small intestine in broiler chickens. Journal of Medicinal Food 10(2), 276-280.

Xu, X., Sun, L., Dong, J. \& Zhang, H. (2009) Breaking the cells of rape bee pollen and consecutive extraction of functional oil with supercritical carbon dioxide. Innovative food science \& emerging technologies 10(1), 42-46. 


\title{
اثر عصاره بره موم و گرده عسل بر يارامترهاى بيوشيميايى و خون شناسى ماهى قزل آلاى رنغين كمان
}

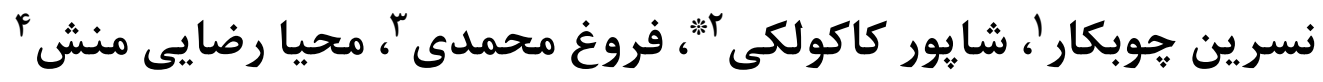 \\ 'كروه شيلات، دانشكده كشاورزى،واحد كرمانشاه، دانشكاه آزاد اسلامى، كرمانشاه، ايران

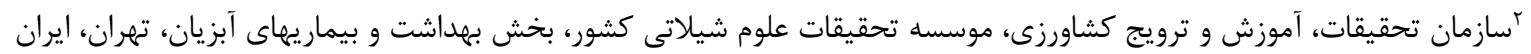

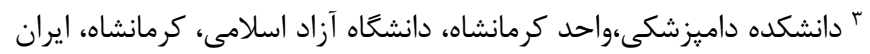

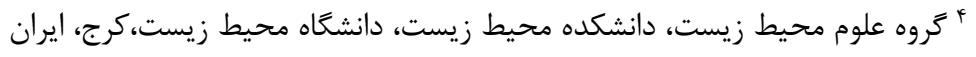

هدف از اين مطالعه تعيين اثر عصاره بره موم و كرده در گارامترهاى بيوشيميايى و خون ماهى قزل الا بود. يك صد و هشتاد ماهى سالم قزل آلا با متوسط وزن

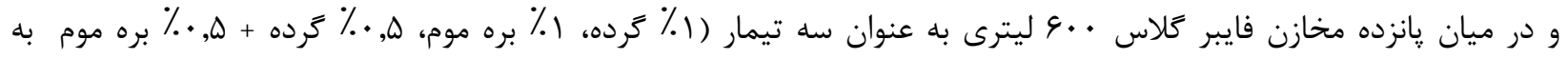

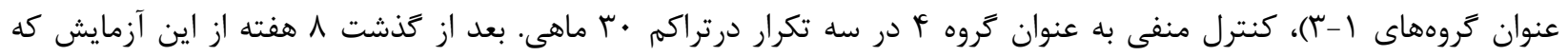
ماهى ها با رزيم غذايى پايه تجارى تغذيه شدند، وزن نهايى، وزن مكتسبه وشاخص رشد روزانه در تمام تيمارها با يكديخر تفاوت

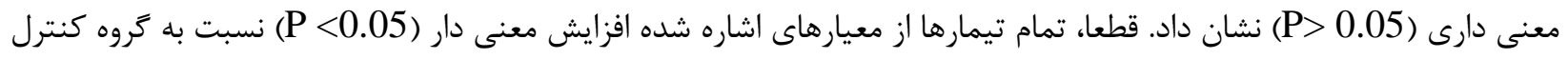

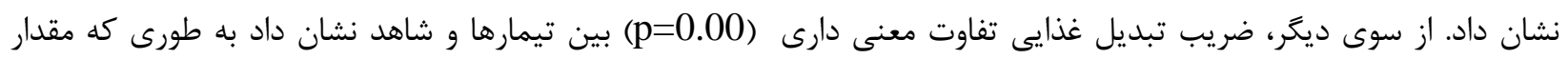
حداقل آن در گروه ץ (ه•|•

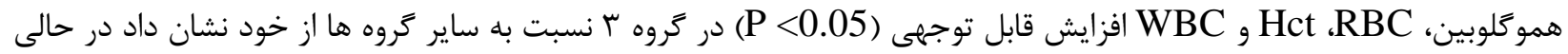
كه MCV و MCH در تروه r (P (P) به طور قابل توجهى پايين تر بود.

كلمات كليدى: گَياه دارويى، گرده، بره موم، ماهى قزل آلا، خون شناسى

bsh443@gmail.com : نويسنده مسئول 